\title{
Treatment of Breast Cancer-Bearing BALB/c Mice with Magnetic Hyperthermia using Dendrimer Functionalized Iron-Oxide Nanoparticles
}

\author{
Marzieh Salimi ${ }^{1,2,3, *(\mathbb{D})}$, Saeed Sarkar ${ }^{2,3}$, Mansoureh Hashemi ${ }^{4}$ and Reza Saber ${ }^{3,5}$ \\ 1 School of Physics and Astronomy, University of Exeter, Exeter EX4 4QL, UK \\ 2 Department of Medical Physics and Biomedical Engineering, Tehran University of Medical Sciences, \\ Tehran 1417613151, Iran; sarkar@tums.ac.ir \\ 3 Research Center of Science and Technology in Medicine, Tehran University of Medical Sciences, \\ Tehran 14185-615, Iran \\ 4 Functional Neurosurgery Research Center, Shahid Beheshti University of Medical Sciences, \\ Tehran 1989934148, Iran; mansoureh.hashemi@sbmu.ac.ir \\ 5 Department of Medical Nanotechnology, School of Advanced Technologies in Medicine, Tehran University \\ of Medical Sciences, Tehran 1417755469, Iran; rsaber@sina.tums.ac.ir \\ * Correspondence: m.a.salimi@exeter.ac.uk; Tel.: +44-1392-725652
}

Received: 23 October 2020; Accepted: 20 November 2020; Published: 22 November 2020

\begin{abstract}
The development of novel nanoparticles for diagnostic and therapeutic applications has been one of the most crucial challenges in cancer theranostics for the last decades. Herein, we functionalized iron oxide nanoparticles (IONPs) with the fourth generation $\left(\mathrm{G}_{4}\right)$ of poly amidoamine (PAMAM) dendrimers $\left(\mathrm{G}_{4} @ \mathrm{IONPs}\right)$ for magnetic hyperthermia treatment of breast cancer in Bagg albino strain C (BALB/c)mice. The survival of breast cancer cells significantly decreased after incubation with $\mathrm{G}_{4} @ \mathrm{IONPs}$ and exposure to an alternating magnetic field (AMF) due to apoptosis and elevation of Bax (Bcl-2 associated X)/Bcl-2(B-cell lymphoma 2) ratio. After intratumoral injection of $\mathrm{G}_{4} @ \mathrm{IONPs}$, tumor-bearing $\mathrm{BALB} / \mathrm{c}$ mice were exposed to $\mathrm{AMF}$ for $20 \mathrm{~min}$; this procedure was repeated three times every other day. After the last treatment, tumor size was measured every three days. Histopathological and Immunohistochemical studies were performed on the liver, lung, and tumor tissues in treated and control mice. The results did not show any metastatic cells in the liver and lung tissues in the treatment group, while the control mice tissues contained metastatic breast cancer cells. Furthermore, the findings of the present study showed that magnetic hyperthermia treatment inhibited tumor growth by increasing cancer cell apoptosis, as well as reducing the tumor angiogenesis.
\end{abstract}

Keywords: dendrimer; iron oxide nanoparticles; magnetic hyperthermia; breast cancer

\section{Introduction}

Breast cancer is the most common cancer in women both in developed and developing countries. In 2018, over 626,679 women died from breast cancer [1,2]. The most common treatment methods for breast cancer, e.g., radiation therapy, surgery, and chemotherapy, possess several side effects, such as secondary cancer, tumor recurrence, and normal tissue damage. Magnetic hyperthermia as a nanotechnology-based method for cancer treatment has attracted lots of attention in recent years [3-7].

In magnetic hyperthermia treatment, magnetic nanoparticles (MNPs) are injected into the tumor and subsequently exposed to an alternating magnetic field (AMF) to transform the magnetic field to heat through several physical mechanisms. Consequently, the temperature of the tumor tissue rises $5-7{ }^{\circ} \mathrm{C}$ above the normal temperature of the body [8]. In this situation and also considering that cancer cells are more sensitive to heat, these cells will be damaged while healthy cells can be spared $[9,10]$. 
The outcome of magnetic hyperthermia treatment depends on MNPs characteristics, such as saturation magnetization, polydispersity, and aggregation [11]. In this regard, iron oxide magnetic nanoparticles (IONPs) are suitable candidates for magnetic hyperthermia due to their high saturation magnetization. On the other hand, one of the major challenges in using IONPs in biomedical studies, in particular magnetic hyperthermia, is their tendency to agglomerate due to the high surface area to volume ratio $[12,13]$. To overcome this issue, it is necessary to use a polymeric coating that first prevents IONPs aggregation, and secondly possesses multiple surface-active functional groups for conjugation to the targeting, imaging, and therapeutic molecules.

Dendrimers are highly branched, star-shaped macromolecules with nanometer-scale architecture, and well suited for biological applications, such as gene delivery, drug delivery, photodynamic therapy, and imaging [4,13-17]. Dendrimers are composed of three components: a central core, an internal dendritic structure called generation, and an external surface with functional groups [18]. Monodisperse dendrimers are synthesized by step-wise chemical approaches (divergent and convergent) to give distinct generations of molecules with uniform size and shape, and multiple surface groups [19]. Poly amidoamine (PAMAM) dendrimers possess a condensed outer amine shell which can react with biomolecules and prevents the agglomeration of IONPs [20]. We have reported the synthesis method of functionalized IONPs with fourth-generation PAMAM dendrimers $\left(\mathrm{G}_{4} @ \mathrm{IONPs}\right)$ in our previous studies [21]. The results showed that the dendrimer coating prevented IONPs aggregation and increase their colloidal stability.

Many studies were performed on magnetic hyperthermia using different functionalized MNPs on animal models of cancer [22-35] (Table 1). Generally speaking, their results were promising and showed a significant remission in the tumor size after treatment. Furthermore, several histological damages and destructions were detected in the treated tumor tissues. Regarding dendrimers are the powerful tools in theranostic applications and a lack of studies using dendrimer functionalized MNPs for magnetic hyperthermia, this study was performed to investigate the therapeutic effects of magnetic hyperthermia using $\mathrm{G}_{4} @ \mathrm{IONPs}$ on breast cancer tumor.

In the present study, $\mathrm{G}_{4} @ I O N P s$ were synthesized via a co-precipitated method and functionalized by adding methyl acrylate/ethylenediamine stepwise to the $\mathrm{G}_{0} @ I O N P$ s solution. Subsequently, the polyethylene glycol coating (PEGylation) procedure was performed to increase MNPs stability. $\mathrm{G}_{4} @ \mathrm{IONPs}$ were characterized by transmission electron microscope (TEM), Fourier-transform infrared spectroscopy (FTIR), and zeta potential measurements. The cytotoxicity of $\mathrm{G}_{4} @ \mathrm{IONPs}$ in mice estrogen receptor-positive breast carcinoma cells $\left(\mathrm{MC}_{4} \mathrm{~L}_{2}\right)$ was evaluated by 3-[4, 5-dimethylthiazol-2yl]-2, 5 diphenyl tetrazolium bromide (MTT) assay. For magnetic hyperthermia treatment, $\mathrm{MC}_{4} \mathrm{~L}_{2}$ were cultured with $\mathrm{G}_{4} @ \mathrm{IONPs}$ for $2 \mathrm{~h}$ and then exposed to the AMF for $120 \mathrm{~min}$. MTT assay, terminal deoxynucleotidyl transferase-mediated dUTP nick-end labeling (TUNEL) staining, and real-time polymerase chain reaction (PCR) were performed to investigate the efficiency of treatment. Breast cancer-bearing BALB/c mice were exposed to the AMF for $20 \mathrm{~min}$ after intratumoral G $@$ IONPs injection. The tumor volume and mortality of mice in all groups were monitored after the last treatment for four and eight weeks, respectively. Liver, lung, and tumor tissues were harvested from control and treated mice eight days after the last treatment and assessed by histopathological staining. Furthermore, apoptosis and angiogenesis in control and treated tumor tissues were studied by TUNEL and Immunohistochemistry assays, respectively (Figure 1). The results showed that magnetic hyperthermia using $\mathrm{G}_{4} @ \mathrm{IONPs}$ could effectively demolish breast cancer cells by increasing apoptosis and inhibit tumor growth by reducing the tumor angiogenesis and perfusion. 
Table 1. Different types of nanoparticles used in the magnetic hyperthermia treatment for cancer-bearing mice.

\begin{tabular}{|c|c|c|c|c|c|c|c|c|}
\hline Study & $\begin{array}{l}\text { MNPs } \\
\text { Core }\end{array}$ & $\begin{array}{l}\text { MNPs } \\
\text { Size }\end{array}$ & Coating & $\begin{array}{l}\text { Treatment } \\
\text { Time }\end{array}$ & $\begin{array}{c}\text { MNPs } \\
\begin{array}{c}\text { Concentration/Type } \\
\text { of Injection }\end{array}\end{array}$ & Tumor Model & AMF & Results \\
\hline $\begin{array}{l}\text { Hayashi et al. } \\
\text { [22] }\end{array}$ & $\mathrm{Fe}_{3} \mathrm{O}_{4}$ & $10.5 \mathrm{~nm}$ & $\begin{array}{l}\text { PPy-PEG-FA } \\
\text { Dox }\end{array}$ & $20 \mathrm{~min}$ & $\begin{array}{l}5 \mathrm{mg} / \mathrm{kg} \text {; intratumoral } \\
\text { injection }\end{array}$ & $\begin{array}{l}\text { Multiple } \\
\text { myeloma }\end{array}$ & $\begin{array}{l}8 \mathrm{kA} / \mathrm{m} \\
230 \mathrm{kHz}\end{array}$ & $\begin{array}{l}\text { The combination of magnetic } \\
\text { hyperthermia treatment and } \\
\text { chemotherapy completely cured the } \\
\text { tumor without any recurrence. }\end{array}$ \\
\hline $\begin{array}{c}\text { Kossatz et al. } \\
\text { [23] }\end{array}$ & SPIONs & $12 \pm 3 \mathrm{~nm}$ & $\begin{array}{l}\text { N6L or/and } \\
\text { DOX }\end{array}$ & $60 \mathrm{~min}$ & $\begin{array}{l}0.25 \mathrm{mg} \mathrm{Fe} / 100 \mathrm{~mm}^{3} \text {; } \\
\text { intratumoral injection }\end{array}$ & Breast & $\begin{array}{c}15.4 \mathrm{kA} / \mathrm{m} \\
435 \mathrm{kHz}\end{array}$ & $\begin{array}{l}\text { Substantial tumor growth inhibition } \\
\text { up to } 40 \% \text { and complete tumor } \\
\text { regression were seen after magnetic } \\
\text { hyperthermia treatment. }\end{array}$ \\
\hline $\begin{array}{l}\text { Haghniaz et al. } \\
\text { [24] }\end{array}$ & $\begin{array}{c}\mathrm{La}_{0.7} \mathrm{Sr}_{0.3} \\
\mathrm{MnO}_{3}\end{array}$ & $25-50 \mathrm{~nm}$ & dextran & $20 \mathrm{~min}$ & $\begin{array}{l}5 \mathrm{mg} / 100 \mu \mathrm{L} \text { saline; } \\
\text { intratumoral injection }\end{array}$ & Melanoma & $\begin{array}{c}700 \mathrm{~A} \\
8000 \mathrm{~W} \\
365 \mathrm{kHz}\end{array}$ & $\begin{array}{l}\text { Treatment inhibited tumor growth } \\
(84 \%) \text { and increased animal survival } \\
(50 \%) \text {. In addition, levels of caspase-3 } \\
\text { and caspase- } 6 \text { also increased } \\
\text { after treatment. }\end{array}$ \\
\hline Lee et al. [25] & $\mathrm{CoFe}_{2} \mathrm{O}_{4}$ & $15 \mathrm{~nm}$ & $\mathrm{MnFe}_{2} \mathrm{O}_{4}$ & $10 \mathrm{~min}$ & $\begin{array}{l}75 \mathrm{mg} \text {; intratumoral } \\
\text { injection }\end{array}$ & Glioblastoma & $\begin{array}{c}37.3 \mathrm{kA} / \mathrm{m} \\
500 \mathrm{kHz}\end{array}$ & $\begin{array}{c}\text { The tumor was clearly eliminated in } 18 \\
\text { days after treatment. }\end{array}$ \\
\hline Li et al. [26] & $\mathrm{Fe}_{3} \mathrm{O}_{4}$ & $22 \mathrm{~nm}$ & $\begin{array}{l}\text { anti-HER2, 5-FU } \\
\text { and PEG }\end{array}$ & $15 \mathrm{~min}$ & $\begin{array}{c}500 \mathrm{mg} / \mathrm{mL} \text { iron; } \\
\text { systematic injection }\end{array}$ & $\begin{array}{l}\text { Bladder } \\
\text { carcinoma }\end{array}$ & $\begin{array}{l}33 \mathrm{kA} / \mathrm{m} \\
1.3 \mathrm{MHz}\end{array}$ & $\begin{array}{l}\text { Prominent tumor remission was seen } \\
\text { after hyperthermia and chemotherapy. }\end{array}$ \\
\hline Rabias et al. [27] & $\mathrm{Fe}_{2} \mathrm{O}_{3}$ & $10-12 \mathrm{~nm}$ & dextran & $20 \mathrm{~min}$ & $\begin{array}{l}150 \mu \mathrm{L} ; \text { intratumoral } \\
\text { injection }\end{array}$ & Glioma & $\begin{array}{l}11 \mathrm{kA} / \mathrm{m} \\
150 \mathrm{kHz}\end{array}$ & $\begin{array}{l}\text { Significant tumor tissue damage and } \\
\text { dissolution were seen after treatment. }\end{array}$ \\
\hline Bae et al. [28] & $\mathrm{Fe}_{3} \mathrm{O}_{4}$ & $30 \mathrm{~nm}$ & Chitosan-DOPA & $20 \mathrm{~min}$ & $\begin{array}{c}375 \mu \mathrm{g} \mathrm{Fe} / \mathrm{kg} ; \\
\text { Intratumoral injection }\end{array}$ & Lung carcinoma & $\begin{array}{l}660 \mathrm{~A} / \mathrm{m} \\
1 \mathrm{MHz}\end{array}$ & $\begin{array}{l}\text { The tumor volume decreased } \\
\text { substantially by about } 70 \% \text {. }\end{array}$ \\
\hline Ling et al. [29] & $\mathrm{Fe}_{3} \mathrm{O}_{4}$ & $20-50 \mathrm{~nm}$ & PMMA & $3 \mathrm{~min}$ & $\begin{array}{l}0.1 \mathrm{~mL} \text {; intratumoral } \\
\text { injection }\end{array}$ & Breast & $\begin{array}{c}28.6 \mathrm{~A} \\
626 \mathrm{kHz}\end{array}$ & $\begin{array}{l}\text { Tumor volume decreased within } \\
15 \text { days after treatment. }\end{array}$ \\
\hline $\begin{array}{c}\text { Arriortua et al. } \\
\text { [30] }\end{array}$ & $\mathrm{Fe}_{3} \mathrm{O}_{4}$ & $19 \pm 2 \mathrm{~nm}$ & RGD peptide & $>21 \mathrm{~min}$ & $\begin{array}{l}1-1.5 \mathrm{mg} \mathrm{Fe} / \mathrm{mL} \\
\text { systemic injection }\end{array}$ & $\begin{array}{l}\text { Colon } \\
\text { adenocarcinoma }\end{array}$ & $\begin{array}{l}14 \mathrm{kA} / \mathrm{m} \\
606 \mathrm{kHz}\end{array}$ & $\begin{array}{l}\text { Tumor necrosis was observed. } \\
\text { Approximately whole tumor tissue } \\
\text { was demolished in some animals, } \\
\text { others showed very low damage in } \\
\text { tumor tissue. }\end{array}$ \\
\hline $\begin{array}{l}\text { Ohtake et al. } \\
\text { [31] }\end{array}$ & Fe(Salen) & $200 \mathrm{~nm}$ & Salen & $60 \mathrm{~min}$ & $\begin{array}{l}0.12-0.60 \mathrm{mg} / \mathrm{body} \\
\text { intratumoral injection }\end{array}$ & Glioblastoma & $\begin{array}{l}335.4 \mathrm{~A} \\
280 \mathrm{kHz}\end{array}$ & $\begin{array}{l}\text { The tumor size was decreased, } \\
\text { by } 80-90 \% \text {, in treatment group after } \\
4 \text { weeks. }\end{array}$ \\
\hline
\end{tabular}


Table 1. Cont

\begin{tabular}{|c|c|c|c|c|c|c|c|c|}
\hline Study & $\begin{array}{l}\text { MNPs } \\
\text { Core }\end{array}$ & $\begin{array}{l}\text { MNPs } \\
\text { Size }\end{array}$ & Coating & $\begin{array}{l}\text { Treatment } \\
\text { Time }\end{array}$ & $\begin{array}{c}\text { MNPs } \\
\begin{array}{c}\text { Concentration/Type } \\
\text { of Injection }\end{array}\end{array}$ & Tumor Model & AMF & Results \\
\hline Sato et al. [32] & Fe(Salen) & $200 \mathrm{~nm}$ & - & $30 \mathrm{~min}$ & $\begin{array}{c}50 \mathrm{mM} \text {; intratumoral } \\
\text { injection }\end{array}$ & Tongue & $\begin{array}{c}250 \mathrm{~A} \\
308 \mathrm{kHz}\end{array}$ & $\begin{array}{l}\text { The tumor volume significantly } \\
\text { decreased }(223 \pm 80.6 \%) \text {. The tumor } \\
\text { almost completely disappeared after } \\
\text { one week. }\end{array}$ \\
\hline Yang et al. [33] & $\mathrm{Fe}_{3} \mathrm{O}_{4}$ & - & PLGA & $3 \mathrm{~min}$ & $\begin{array}{c}100 \mu \mathrm{L} ; \\
\text { intratumoral injection }\end{array}$ & $\begin{array}{l}\text { Hepatic } \\
\text { carcinoma }\end{array}$ & $\begin{array}{c}28.6 \mathrm{~A} \\
626 \mathrm{kHz}\end{array}$ & $\begin{array}{l}\text { Coagulative necrosis was seen in } \\
\text { cancer tissues after treatment. } \\
\text { In addition, anti-tumor immune } \\
\text { system was activated in treated mice } \\
\text { and promoted apoptosis in tumor } \\
\text { cells. }\end{array}$ \\
\hline Zhang et al. [34] & $\mathrm{Fe}_{3} \mathrm{O}_{4}$ & $18 \mathrm{~nm}$ & PPZ polymer & $60 \mathrm{~min}$ & $\begin{array}{c}0.8 \mu \mathrm{L} / \mathrm{mm}^{3} \\
\text { intratumoral injection }\end{array}$ & Glioblastoma & $\begin{array}{c}13.3 \mathrm{kA} / \mathrm{m} \\
366 \mathrm{kHz}\end{array}$ & $\begin{array}{l}\text { The tumor size was significantly } \\
\text { smaller than the control } 25 \text { days after } \\
\text { the last treatment. Pyknosis, } \\
\text { karyorrhexis, and apoptosis were seen } \\
\text { in treated tumor tissues. }\end{array}$ \\
\hline $\begin{array}{c}\text { Hayashi et al. } \\
\text { [35] }\end{array}$ & SPIONs & $7-9 \mathrm{~nm}$ & PEG and FA & $20 \mathrm{~min}$ & $\begin{array}{c}48 \mu \mathrm{mol} \mathrm{Fe} / \mathrm{kg} ; \\
\text { systematic injection }\end{array}$ & $\begin{array}{l}\text { Multiple } \\
\text { myeloma }\end{array}$ & $\begin{array}{c}8 \mathrm{kA} / \mathrm{m} 230 \\
\mathrm{kHz}\end{array}$ & $\begin{array}{l}\text { Tumor volume in treated mice was } \\
\text { one-tenth of control in } 35 \text { days after } \\
\text { treatment }\end{array}$ \\
\hline
\end{tabular}

Abbreviations: SPIONs, superparamagnetic iron oxide nanoparticle; DOX, doxorubicin; HER2, human epidermal growth factor receptor; FU, fluorouracil; PPy, polypyrrole; FA, folic acid; DOPA, dihydroxyphenylalanine; PMMA, polymethyl methacrylate; RGD, arginylglycylaspartic acid; PLGA, poly(lactic-co-glycolic acid); PPZ, polyorganophosphazene. 


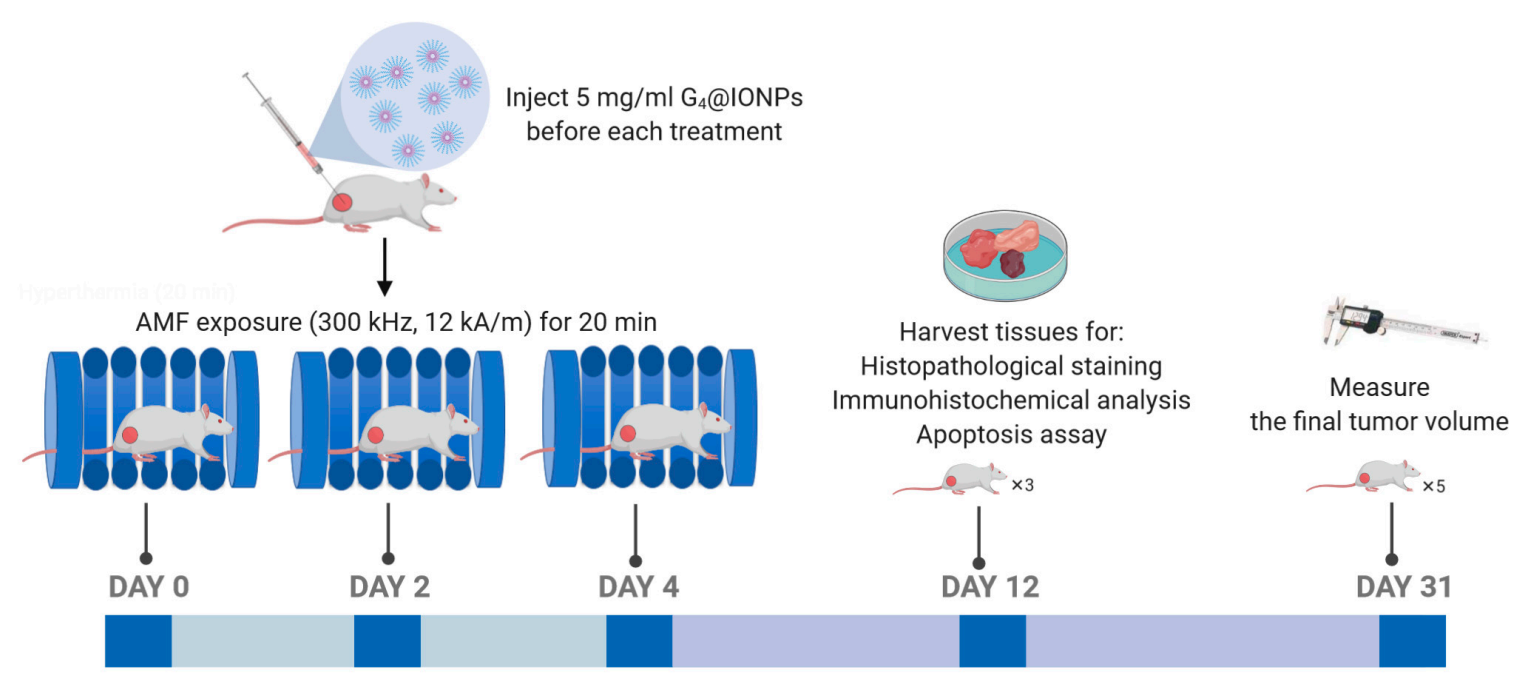

Figure 1. Experimental workflow for magnetic hyperthermia treatment in breast cancer-bearing $\mathrm{BALB} / \mathrm{c}$ mice.

\section{Materials and Methods}

\subsection{Chemicals and Materials}

Ferric chloride hexahydrate $\left(\mathrm{FeCl}_{3}, 6 \mathrm{H}_{2} \mathrm{O}, 99 \%\right.$ w/w), ferric sulfate heptahydrate $\left(\mathrm{FeSO}_{4} \cdot 7 \mathrm{H}_{2} \mathrm{O}\right.$, $99 \% w / w)$, hydrochloric acid $(\mathrm{HCl}, 32 \% v / v)$, methanol $(99.9 \% v / v)$, ammonia solution $\left(\mathrm{NH}_{3}, 32 \% v / v\right)$, 3-aminopropyltriethoxysilane $\left(\mathrm{NH}_{2}\left(\mathrm{CH}_{2}\right)_{3}-\mathrm{Si}-\left(\mathrm{OCH}_{3}\right)_{3}\right.$, methyl acrylate $(99.5 \% \mathrm{v} / \mathrm{v})$, (3-Aminopropyl) triethoxysilane (APTS), ethanol (99.9\% v/v), methoxy-PEG and ethylenediamine (99\% $v / v)$, fetal bovine serum (FBS), dimethyl sulfoxide (DMSO), Eagle's minimal essential medium (DEMEM), and PenStrep were purchased from Sigma-Aldrich (Hamburg, Germany).

\subsection{Magnetic Nanoparticles Synthesis}

$\mathrm{G}_{4} @ \mathrm{IONPs}$ synthesis and characterization were explained in detail in our previous studies $[21,36]$. Briefly, IONPs were synthesized by co-precipitation of $0.84 \mathrm{~g}$ of $\mathrm{FeSO}_{4}$ and $1.22 \mathrm{~g}$ of $\mathrm{FeCl}_{3}$ and then functionalized by PAMAM dendrimers with step by step addition of methyl acrylate and Ethylenediamine (Figure 2a). $50 \mathrm{~mL}$ methyl acrylate/methanol solution $(20 \%, v / v)$ was added to the $10 \mathrm{~mL}$ ethanol solution of APTS coated IONPs (5 g/L); after 1h sonication and stirring, $15 \mathrm{~mL}$ ethylenediamine/methanol $(50 \%, v / v)$ was added to the previous solution followed by $3 \mathrm{~h}$ sonication at room temperature. Subsequently, methoxypolyethylene glycol (mPEG) molecules (molecular weight = $4000 \mathrm{Da}$ ) having three times the mass of the iron were dissolved in ethanol and added to the $\mathrm{G}_{4} @ \mathrm{IONPs}$ solution before $18 \mathrm{~h}$ reflux. Transmission electron microscopy (TEM) and Fourier transform infrared (FTIR) spectroscopy were applied to assess $\mathrm{G}_{4} @$ IONPs size and presence of PAMAM bonds on the IONPs surface, respectively. In addition,, the surface charge of $\mathrm{G}_{4} @ I O N P$ s was measured using a Zetasizer instrument (Malvern Panalytical, Malvern, UK). 

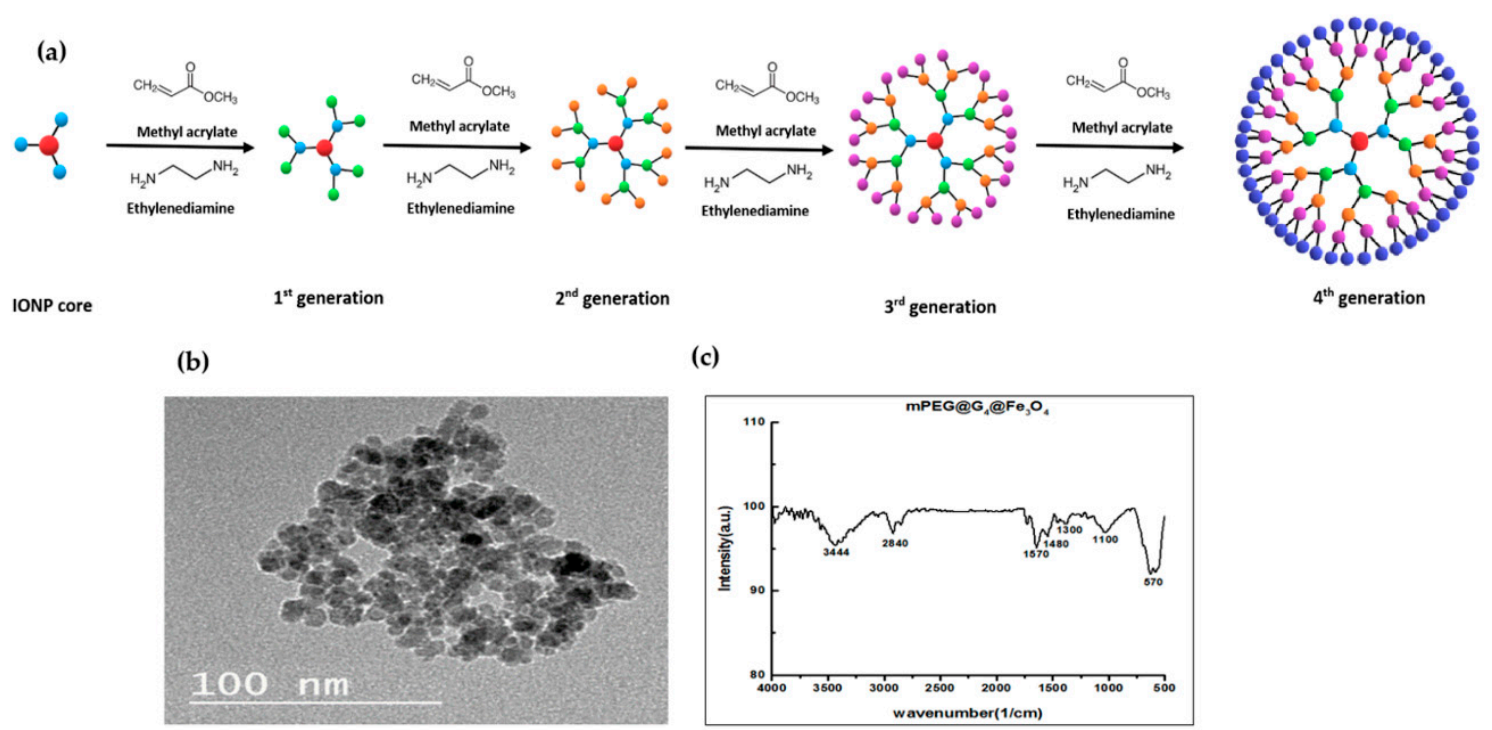

(c)

Figure 2. (a) Schematic illustration of functionalization of iron oxide magnetic nanoparticles (IONPs) with G4 poly amidoamine (PAMAM) dendrimers, (b) transmission electron microscope (TEM) image of $\mathrm{G}_{4} @ \mathrm{IONPs}$, (c) Fourier-transform infrared spectroscopy (FTIR) spectra for PEGylated $\mathrm{G}_{4} @ \mathrm{IONPs}$.

\subsection{Cell Culture}

$\mathrm{MC}_{4} \mathrm{~L}_{2}$ breast cancer cells were obtained from the Pasteur Institute (Tehran, Iran) and cultured in DMEM medium supplemented with $10 \%(v / v) \mathrm{FBS}$, and $1 \%$ Pen-Strep at $37^{\circ} \mathrm{C}$ and $5 \% \mathrm{CO}_{2}$. Cytotoxicity of $\mathrm{G}_{4} @ \mathrm{IONPs}$ Cytotoxicity of $\mathrm{G}_{4} @ \mathrm{IONPs}$ was evaluated by MTT assay. After $24 \mathrm{~h}$ incubation, $\mathrm{MC}_{4} \mathrm{~L}_{2}$ cells were washed with PBS twice and treated with different $\mathrm{G}_{4} @$ IONPs concentrations of 1500, 1000, $500,100,10$, and $0 /$ control $\mu \mathrm{g} / \mathrm{mL}$ for $24 \mathrm{~h}$. The culture media were then removed, and the MTT solution was added to each well for $4 \mathrm{~h}$. Finally, $100 \mu \mathrm{L}$ DMSO was added and the absorbance of wells was read using an ELISA (enzyme-linked immunosorbent assay) plate reader (Hyperion, microplate reader MPR4+) at $540 \mathrm{~nm}[37]$.

\subsection{Magnetic Hyperthermia Treatment in Cancer Cells}

$\mathrm{MC}_{4} \mathrm{~L}_{2}$ cells were divided into four experimental groups: MNPs + AMF, AMF, MNPs, and control. In the group of MNPs + AMF, cells were cultured with $500 \mu \mathrm{g} / \mathrm{mL} \mathrm{G}_{4} @ \mathrm{IONPs}$ for $2 \mathrm{~h}$ and then exposed to the AMF ( $300 \mathrm{kHz}$ and $12 \mathrm{kA} / \mathrm{m}$; LABA, HT-1000W, Nanotechnology System Corporation (NATSYCO), Tehran, Iran) for $120 \mathrm{~min}$. The other cells were only exposed to the AMF (AMF group) or cultured with $500 \mu \mathrm{g} / \mathrm{mL} \mathrm{G}_{4} @ \mathrm{IONPs}$ (MNPs group). Control cells received neither $\mathrm{G}_{4} @ \mathrm{IONPs}$ nor AMF exposure. MTT assay was performed to assess the cellular viability in all group (Figure 3a).

\section{5. $G_{4} @ I O N P s$ Cellular Uptake and Localization}

Cellular uptake of $\mathrm{G}_{4} @ \mathrm{IONPs}$ was evaluated by Prussian blue staining and measured by Inductively Coupled Plasma Mass Spectrometry (ICP-MS) [38,39]. Different concentrations of $\mathrm{G}_{4} @ \mathrm{IONPs}(500,250,100,50$, and 0 (control) $\mu \mathrm{g} / \mathrm{mL}$ ) were added to cell culture media. After $2 \mathrm{~h}$ incubation, cells were fixed with $4 \%$ formalin and incubated with $4 \%$ potassium ferrocyanide and $4 \%$ hydrochloric acid $(50 \%, v / v)$ for $20 \mathrm{~min}$. Finally, the $\mathrm{G}_{4} @ \mathrm{IONPs}$ cellular localization was observed by optical microscopy (Olympus, Tokyo, Japan). Furthermore, $\mathrm{MC}_{4} \mathrm{~L}_{2}$ cells were trypsinized after $2 \mathrm{~h}$ incubation with $\mathrm{G}_{4} @ \mathrm{IONPs}(500,250,100,50$, and 0 (control) $\mu \mathrm{g} / \mathrm{mL}$ ) and lysed by $2 \mathrm{~mL} 65 \%$ nitric acid; the quantity of cellular uptake of $\mathrm{G}_{4} @ \mathrm{IONPs}$ was assessed using ICP-MS (Varian Inc, Palo Alto, CA, USA). To obtain the iron concentration per cell, the total iron concentration measured by ICP-MS was divided by the number of lysed cells. 
(a)
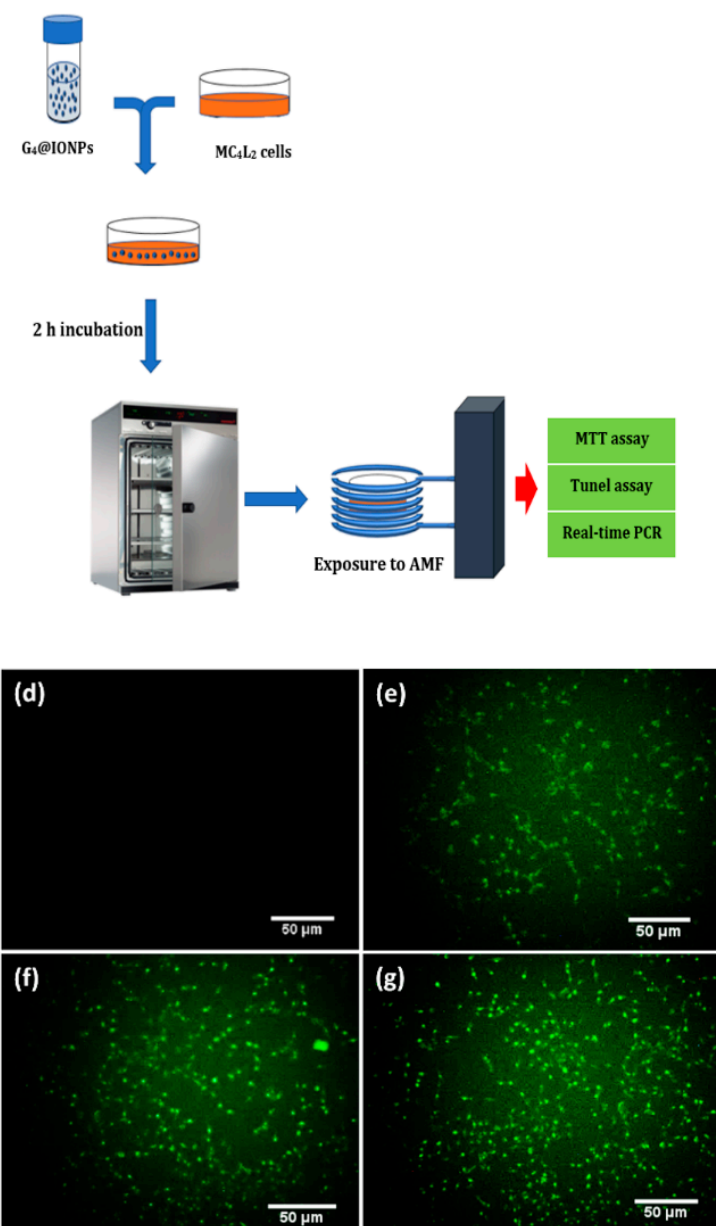

(b)

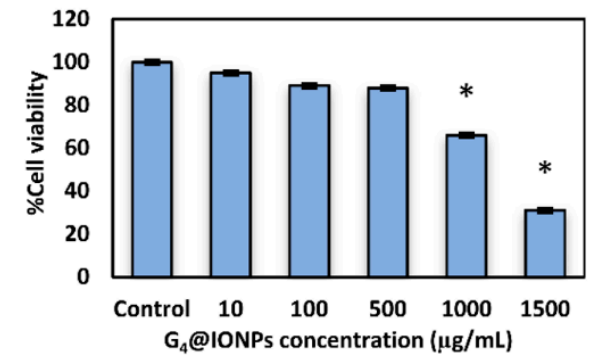

(c)

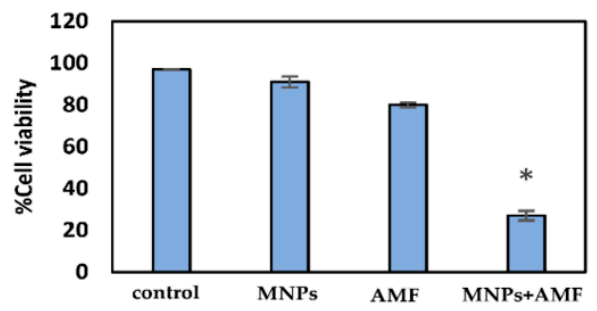

(h)

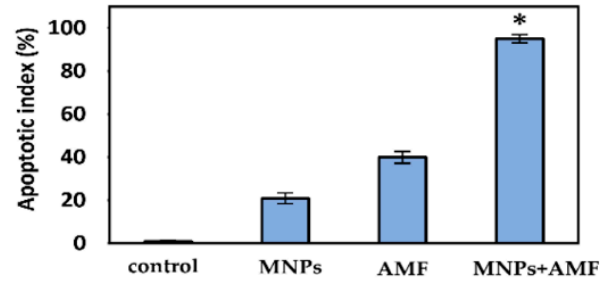

(i)

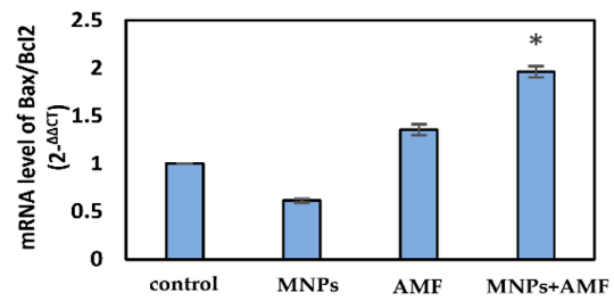

Figure 3. (a) Schematic illustration of magnetic hyperthermia in vitro experiments. $2 \times 105 \mathrm{MC}_{4} \mathrm{~L}_{2}$ cells were seeded in a $35 \mathrm{~mm}$ culture dish overnight. $500 \mu \mathrm{g} / \mathrm{mL} \mathrm{G}_{4} @ \mathrm{IONPs}$ was added to cell culture media. After $2 \mathrm{~h}$ incubation, cells were exposed to alternating magnetic field (AMF) for $120 \mathrm{~min}$. MTT and TUNEL assays, and real-time polymerase chain reaction (PCR) were performed to assess cell viability, apoptosis and Bax/Bcl2 ratio immediately after treatment; (b) Cytotoxicity of $\mathrm{G}_{4} @ \mathrm{IONPs}$ in $\mathrm{MC}_{4} \mathrm{~L}_{2}$ cells $\left({ }^{*} P<0.05\right)$; (c) $\mathrm{MC}_{4} \mathrm{~L}_{2}$ cells viability percentage after magnetic hyperthermia treatment $\left({ }^{*} P<0.05\right)$; TUNEL staining showed the apoptotic cancer cells in groups of: (d) control; (e) magnetic nanoparticles (MNPs); (f) AMF; (g) MNPs + AMF; (h) Apoptotic index in all groups ( $\left.{ }^{*} P<0.05\right)$; (i) Bax/Bcl-2 ratio in $\mathrm{MC}_{4} \mathrm{~L}_{2}$ cells after magnetic hyperthermia treatment $\left({ }^{*} P<0.05\right)$.

\subsection{Apoptotic Cell Death Assessment}

Apoptosis in cancer cells after magnetic hyperthermia treatment was assessed by terminal deoxynucleotidyl transferase dUTP ( 2 '-deoxyuridine- 5 '-triphosphate) nick end labeling (TUNEL) assay. Briefly, $\mathrm{MC}_{4} \mathrm{~L}_{2}$ cells were fixed by $4 \%$ paraformaldehyde for $10 \mathrm{~min}$ and permeabilized with $0.2 \%$ Triton X-100 for 2 min on the ice and then incubated with TUNEL reaction mixture. For the positive and negative control, cells were treated with $5 \%$ ethanol and label solution, respectively [40]. The apoptotic index was the number of apoptotic cells divided by the total number of cells.

\subsection{Effect of Magnetic Hyperthermia Treatment on the Expression of Apoptosis-related Genes}

Expression of Bax and Bcl-2 in $\mathrm{MC}_{4} \mathrm{~L}_{2}$ cells was measured with real-time $\mathrm{PCR}$ followed by magnetic hyperthermia treatment. Complementary DNA (cDNA) was synthesized using RevertAid First Strand cDNA Synthesis Kit (Fermentas, Germany) based on the manufacturer's protocol. Quantification 
of gene expression was done with RotorGene 6000 detection system (Corbett Research, Australia).

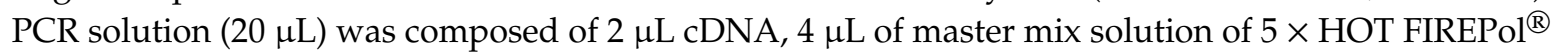
EvaGreen ${ }^{\circledR}$ qPCR Mix Plus kit (ROX), and $0.5 \mu \mathrm{L}$ of each primer. The Bax/Bcl-2 level was normalized to the glyceraldehyde 3-phosphate dehydrogenase (GAPDH, housekeeping gene) transcript and calculated utilizing the $2^{-\Delta \Delta \mathrm{Ct}}$ method (Table 2) [41].

Table 2. Oligonucleotide sequences of interest and reference genes.

\begin{tabular}{ccc}
\hline Gene & Sequences $\left(\mathbf{5}^{\prime} \boldsymbol{\rightarrow} \mathbf{3}^{\prime}\right)$ & Product Size, $\mathbf{b p}$ \\
\hline GAPDH-F & AAGTTCAACGGCACAGTCAAGG & 22 \\
GAPDH-R & CATACTCAGCACCAGCATCACC & 22 \\
Bax-F & AGGGTGGCTGGGAAGGC & 17 \\
Bax-R & TGAGCGAGGCGGTGAGG & 17 \\
Bcl2-F & ATCGCTCTGTGGATGACTGAGTAC & 24 \\
Bcl2-R & AGAGACAGCCAGGAGAAATCAAAC & 24 \\
\hline
\end{tabular}

\subsection{Ethical Statement and Animal Welfare}

The animal experiments were approved by the Animal Ethics Committee of Tehran University of Medical Sciences (IR.TUMS. REC.28169); Applied Research Ethics National Association guidelines were administered for animal welfare. Six- to eight-week-old female BALB/c mice (25-30 g) were purchased from the Animal Center of Pasture Research Center. The groups of five were kept in the individual cages with unlimited access to water and food, and the circadian rhythm was $12 \mathrm{~h}$ in the light and $12 \mathrm{~h}$ in the dark.

\subsection{Breast Tumor Induction in $B A L B / c$ Mice}

$\mathrm{MC}_{4} \mathrm{~L}_{2}$ cells $\left(1 \times 10^{6} / 0.1 \mathrm{~mL}\right)$ were injected into the right inguinal flank of the female mice under ketamine and xylazine anesthesia. The tumor size was measured regularly using a digital Vernier caliper (Mitutoyo, Kawasaki, Japan) and calculated using the following equation:

$$
V\left(\mathrm{~mm}^{3}\right)=\left(L \times W^{2}\right) \times 0.5,
$$

where $V=$ tumor volume, $L=$ Length, and $W=$ Width.

Two weeks post cell injection, the mice with the tumor $\geq 50 \mathrm{~mm}^{3}$ were taken and randomly divided into four groups: control, $\mathrm{G}_{4} @ \mathrm{IONPs}$ injection (MNPs), AMF exposure (AMF), and treatment (MNPs + AMF).

\subsection{Magnetic Hyperthermia Treatment in BALB/c Mice}

$\mathrm{G}_{4} @ \mathrm{IONPs}(5 \mathrm{mg} / \mathrm{mL})$ were injected intratumorally under ketamine and xylazine anesthesia; then, the mouse was transferred into the magnetic coil and exposed to the AMF ( $300 \mathrm{kHz}$ and $12 \mathrm{kA} / \mathrm{m}$ ) for $20 \mathrm{~min}$. The treatment procedure was repeated three times for each animal of the MNPs+AMF group, every other day.

\subsection{Histopathological Studies in Liver, Lung, and Tumor Tissues}

Three mice in each group were euthanized eight days post-treatment. Harvested tissues (liver, lung, and tumor) were fixed in the $10 \% \mathrm{NBF}$ (neutral buffered formalin, $\mathrm{pH} 7.26$ ) for $48 \mathrm{~h}$, then processed and embedded in paraffin. The $5 \mu \mathrm{m}$ thick sections were prepared and stained with Hematoxylin and eosin (H\&E). The histological slides were evaluated by an independent reviewer, using light microscopy (Olympus, Tokyo, Japan). Histopathological evaluation was performed using the Nottingham histologic grading system (Elston-Ellis modification of the Scarff-Bloom-Richardson grading system) for breast cancer [42]. This scoring system grades the breast tumor malignancy between 3 and 9 based on the following features: the amount of gland formation (acinar or tubular differentiation), the nuclear 
features (pleomorphism), and the mitotic activity, which were scaled from 1-3. A tumor with a sum of 3-5 was considered as Grade 1 (well-differentiated). A tumor with a sum of 6-7 and 8-9 was considered as Grade 2 (moderately differentiated) and Grade 3 (poorly differentiated), respectively. Moreover, any changes, including metastasis, inflammatory response, coagulative necrosis, hemorrhage, and hyperemia, were assessed in different groups, comparatively.

\subsection{Immunohistochemistry (IHC) Assay in Tumor Tissues}

The angiogenesis index in tumor tissues was assessed using a monoclonal mouse anti-human cluster of differentiation $34\left(\mathrm{CD}_{34}\right)$ antibody (ready to use, Biocare, Pacheco, CA, USA) in control and treatment mice. This index was defined by counting the positive staining for $\mathrm{CD}_{34}$ in five fields at $200 \times$ magnification, using computer software Image-Pro Plus®V.6 (Media Cybernetics, Inc., Silver Spring, MD, USA), and the results were expressed as the mean number of vessels \pm standard error of the mean (SEM). The negative control sections were obtained by omitting the primary antibody for $\mathrm{CD}_{34}$.

\subsection{Apoptosis in the Tumor Tissues (TUNEL Assay)}

TUNEL assay (TUNEL Assay Kit-BrdU-Red, ab66110) was utilized to determine if treatment inhibited the tumor tissue growth. The number of apoptotic cells was counted in three high-power fields (40× magnification), and the mean percentage of apoptotic cells was reported.

\subsection{Statistical Analysis}

Results were obtained from three independent experiments and reported as the mean \pm SEM. One-way analysis of variance (ANOVA) was used to compare the means in the groups. Statistical differences were significant when $\mathrm{P}<0.05$.

\section{Results}

\subsection{Characterization of $G_{4} @ I O N P s$}

$\mathrm{G}_{4} @ I O N P s$ characterization has been explained in detail in our previous paper [21]. Briefly, the results of TEM showed that the size of nanoparticles was $10 \pm 4 \mathrm{~nm}$ (Figure $2 \mathrm{~b}$ ). The surface charge of $\mathrm{G}_{4} @ \mathrm{IONPs}$ determined by zeta potential measurement was $+35 \mathrm{mV}$ at $\mathrm{pH}=7$ and $25^{\circ} \mathrm{C}$. Zeta potential is an indicator of surface charge that can be used to predict the MNPs solution stability and also is a crucial parameter for the interaction of $\mathrm{G}_{4} @ \mathrm{IONPs}$ with biological systems in vivo. FTIR demonstrated the presence of $\mathrm{Fe}_{3} \mathrm{O}_{4}$ core, dendrimer coating, and mPEG molecules in the $\mathrm{G}_{4} @ \mathrm{IONPs}$ structure. Magnetite core was detected by a strong peak at $570 \mathrm{~cm}^{-1}$ [43]. The peaks at 1450 , 1490, 1570, and $1620 \mathrm{~cm}^{-1}$ confirmed the existence of -CO-NH- bonds related to PAMAM dendrimer on the surface of IONPs. In addition,, the absorption bond at $2888 \mathrm{~cm}^{-1}$ and $1110 \mathrm{~cm}^{-1}$ was attributed to the $\mathrm{C}-\mathrm{H}$ and $\mathrm{C}-\mathrm{O}$ bond of $\mathrm{mPEG}$, respectively (Figure 2c) [44-46].

\subsection{Cytotoxicity of $G_{4} @ I O N P s$ in Cancer Cells (MTT Assay)}

The MTT assay was performed to investigate the toxic effect of $\mathrm{G}_{4} @ \mathrm{IONPs}$ on $\mathrm{MC}_{4} \mathrm{~L}_{2}$ cells at different concentrations. The results showed that $\mathrm{G}_{4} @ \mathrm{IONPs}$ did not have significant cytotoxicity at concentrations up to $500 \mu \mathrm{g} / \mathrm{mL}$. The cell viability reduced significantly at 1000 and $1500 \mu \mathrm{g} / \mathrm{mL}$ (66\% and $31 \%$, respectively) (Figure $3 b)$.

\subsection{Effect of Magnetic Hyperthermia Treatment on the Viability of Cancer Cells}

MTT assay results showed that magnetic hyperthermia treatment (HT + MNPs) significantly decreased cancer cells viability $(41.7 \pm 2.3 \%)$. Furthermore, cell viability was $91.3 \pm 1.1 \%$ and $97.8 \pm$ $2.6 \%$ in groups of MNPs-HT and HT-MNPs, respectively (Figure 3c). 


\subsection{Cellular Apoptosis and Expression of Apoptosis-Related Genes after Magnetic Hyperthermia Treatment}

The results of the TUNEL assay indicated that the number of apoptotic cells in the treatment group (MNPs + AMF) was significantly higher than that in the control group (apoptotic index $=86 \%$ ). On the other hand, the number of apoptotic cells in groups of MNPs and AMF did not have a significant difference with the control group (14\% and $27 \%$, respectively) (Figure $3 \mathrm{~d}-\mathrm{h}$ ). The expression of Bax in cancer cells increased significantly $(P<0.05)$ after magnetic hyperthermia treatment (MNPs + AMF) compared to that in control group; Furthermore, Bcl-2 expression decreased significantly $(P<0.05)$ in the group of MNPs + AMF (Figure 3i).

\subsection{Cellular Uptake and Localization of $G_{4} @ I O N P s$}

Prussian blue staining was performed to demonstrate the cellular uptake of $\mathrm{G}_{4} @ \mathrm{IONPs}$ after $2 \mathrm{~h}$. The iron particles were seen as blue precipitates which increased in the cell cytoplasm with increasing the $\mathrm{G}_{4} @ I O N P$ s concentration (Figure $\left.4 a-e\right)$. Consequently, ICP-MS results revealed that the iron concentration in the cells increased in a concentration-dependent manner. The amount of $16.1 \pm 2.7 \mathrm{pg}$ iron was detected in control cells (Figure $4 \mathrm{f}$ ).

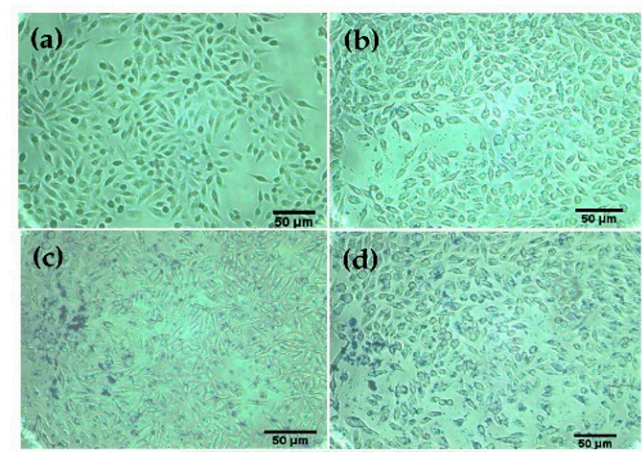

(e)

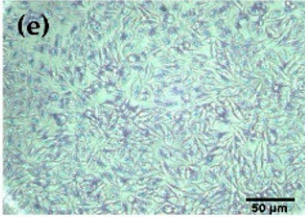

(f)

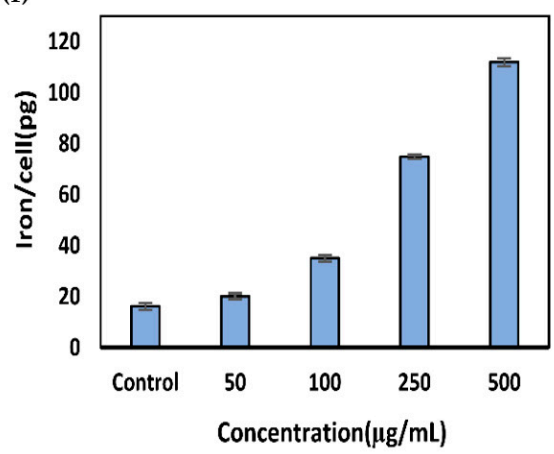

Figure 4. Prussian blue staining illustrated the density of iron oxide nanoparticles inside the $\mathrm{MC}_{4} \mathrm{~L}_{2}$ cells after $2 \mathrm{~h}$ incubation with (a) control; (b) 50; (c) 100; (d) 250; (e) $500 \mu \mathrm{g} / \mathrm{mL}$ of $\mathrm{G}_{4} @ \mathrm{IONPs}$; the iron particles appeared as blue precipitates in the cell cytoplasm; (f) the cellular uptake of $\mathrm{G}_{4} @ \mathrm{IONPs}$ at different concentrations was measured by Inductively Coupled Plasma Mass Spectrometry (ICP-MS).

\subsection{Histopathological Effects of Magnetic Hyperthermia Treatment on Liver and Lung Tissues}

All H\&E-stained lung and liver sections from control and treatment groups were evaluated histologically (Figure 5). Focal metastasis of breast cancer (stars) was seen in the control group (thick arrows). Moreover, hemorrhage, necrosis, and infiltration of inflammatory cells were detected in control tissues due to the invasion of tumor cells. The treatment group showed only mild edema in liver tissue. The histology of the lung tissue in the treatment group was normal without any significant histopathological change. 


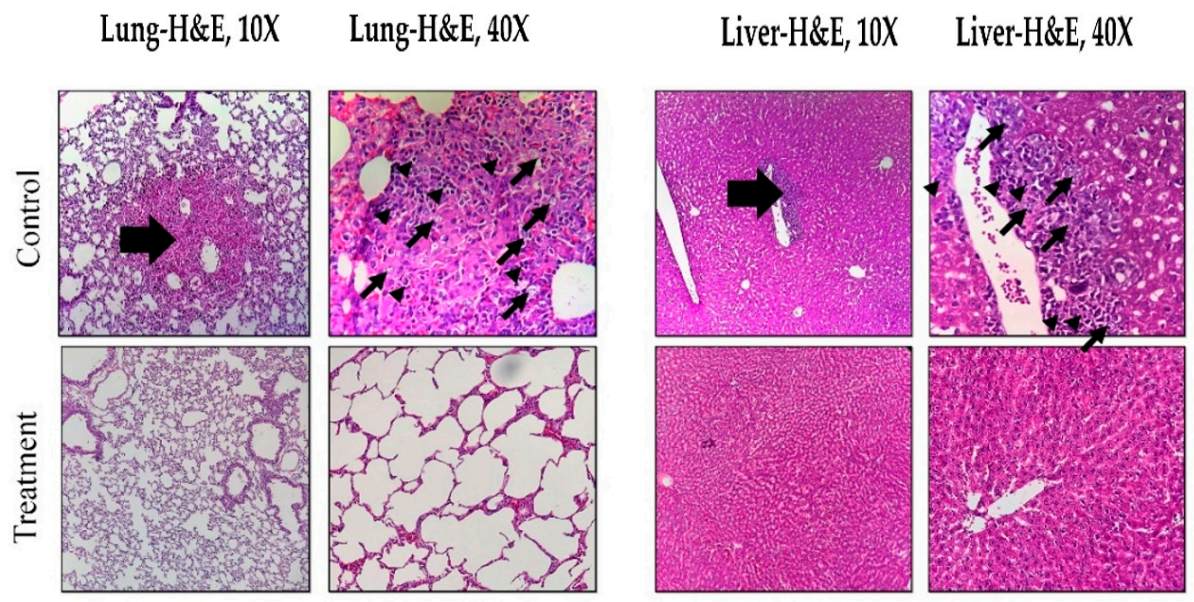

Figure 5. Histopathological images of lung and liver tissues in control and treatment (MNPs + AMF) groups. Thick arrows show microscopic tumor metastasis in lung and liver, thin arrows represent tumor cells, and arrowheads: inflammatory cells.

\subsection{Histopathological Effects of Magnetic Hyperthermia Treatment on Tumor Tissue}

Tumor sections from control and treated mice (MNPs + AMF) were graded histologically using the Nottingham histologic grading system. Many disproportionate tumor cells (anisocytosis), nuclear polymorphism (anisokaryosis, +3 ), and prominent nucleoli were seen in control animals. Moreover, in the control group, glandular (acinar/tubular) differentiation (GD) was low (+3), and the mitotic index in 10 HPF $(400 \times)$ was +3 . Overall, the tumor in the control group was considered as Grade 3 (poorly differentiated) (Figure 6a). In the treatment group, nuclear polymorphism (+1), GD (+2), and the mitotic index in 10 high power microscopic fields $(\mathrm{HPF})(+1)$ were decreased in comparison to the control group. The tumor in the treatment group was considered as Grade 1 (well-differentiated); furthermore, massive necrosis was seen in breast cancer cells in the treatment group (Figure 6a,b).

\subsection{Angiogenesis and Apoptosis in Tumor Tissue after Magnetic Hyperthermia Treatment}

The microvessel density (angiogenesis) in treated tumors with magnetic hyperthermia was $13.4 \pm$ 2.4 per HPF compared to that in control tumors $(51.3 \pm 4.5-P<0.01)$ (Figure $6 \mathrm{a}, \mathrm{c})$. The proportion of apoptotic-positive cells in the treatment group was significantly higher than that in the control group $(P<0.01$, Figure 6a,d).

\subsection{Effect of Magnetic Hyperthermia Treatment on Tumor Volume}

After the last treatment, tumor volume was measured in all groups every three days for four weeks. The final tumor volume in the group of treatment $\left(30.83 \mathrm{~mm}^{3}\right)$ was significantly less than that in the control group $\left(448.11 \mathrm{~mm}^{3}\right.$ ) (Figure $\left.6 \mathrm{e}, \mathrm{f}\right)$.

\subsection{Kaplan-Meier Curve and Survival Rate of BALB/c Mice}

Kaplan-Meier curve illustrated the survival rate of BALB/c mice over time in different groups. Five mice in each group were watched for eight weeks after the last treatment. There was no mortality in treated BALB/c mice during this period, while all other mice died during six weeks (Figure $6 \mathrm{~h}$ ). 
(a)

H\&E, 10X

H\&E, 40X

CD34, 40X

TUNEL, 40X
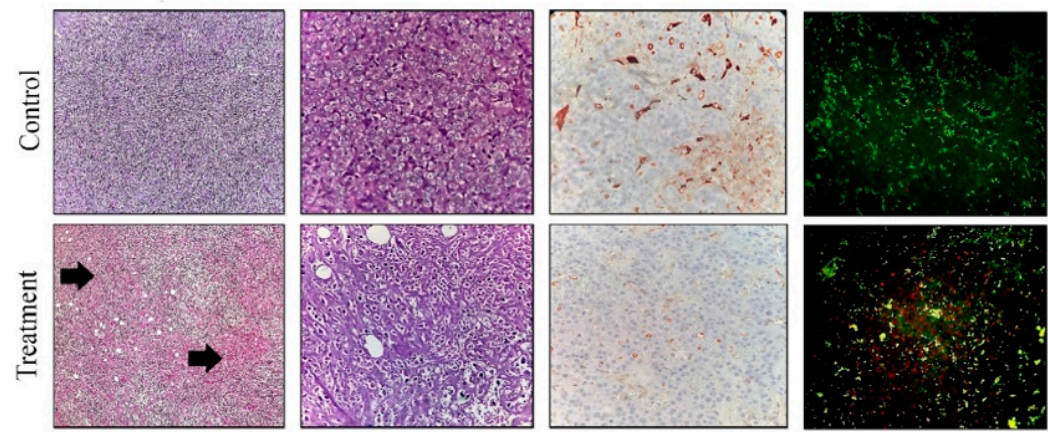

(b)

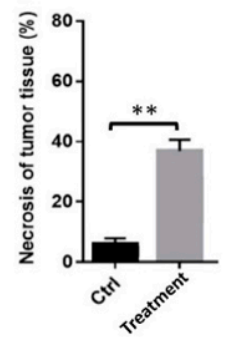

(c)

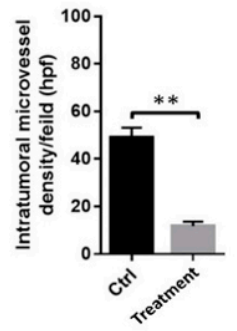

(d)
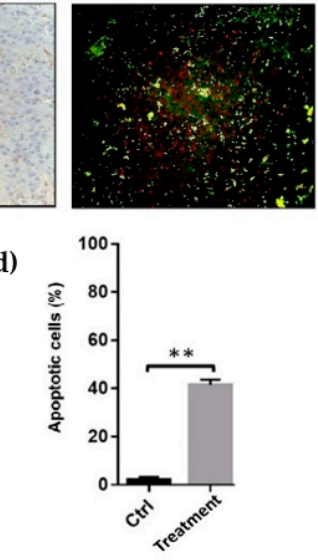

(e)

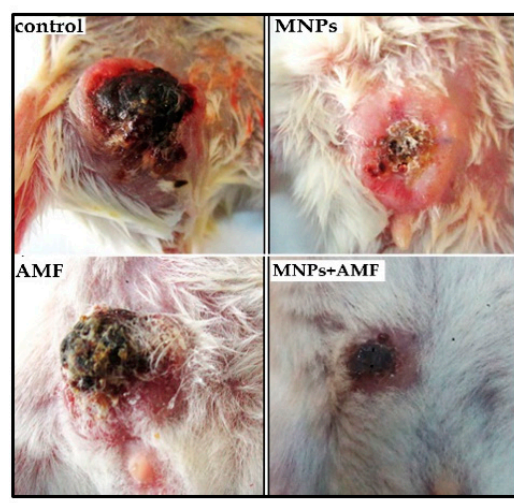

(g)

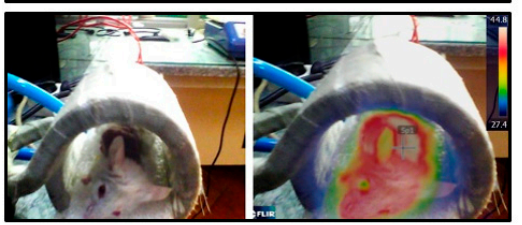

(f) ${ }^{600} \rightarrow$ MNPs+AMF
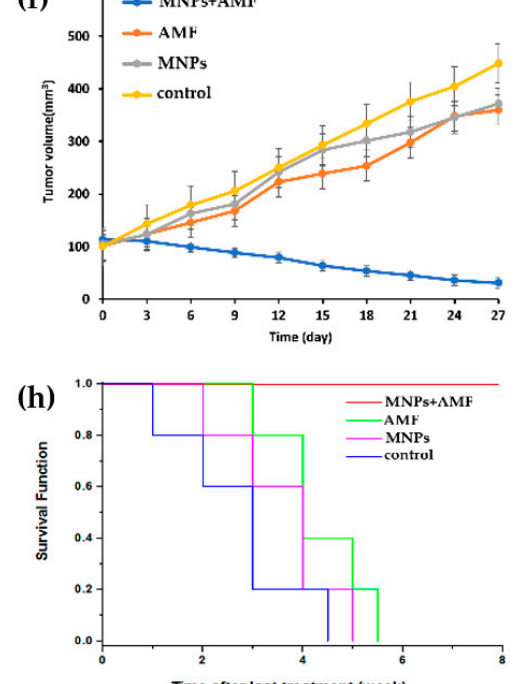

Figure 6. (a) Histopathology, immunohistochemistry, and TUNEL assay of breast cancer tissues in control and treated BALB/c mice; (b) necrosis of tumor tissue (arrows in histopathological image); (c) Immunohistochemical analysis of the cluster of differentiation $34\left(\mathrm{CD}_{34}\right)$ marker was performed to determine the angiogenesis in tumor tissues. The brown color represents positive staining of $\mathrm{CD}_{34}$ cell marker; (d) TUNEL assay was performed to assess the apoptotic cells in the experimental groups. The number of apoptotic-positive cells significantly increased in the treatment group compared to control, red florescent-stained cell nucleus represents apoptotic cells $\left({ }^{* *} p<0.01\right)$; (e) tumor shape and appearance in different experimental groups 27 days after the last treatment; (f) tumor volume versus time after the last treatment in different groups: magnetic hyperthermia using $\mathrm{G}_{4} @ I O N P s$, only AMF exposure, only $\mathrm{G}_{4} @ \mathrm{IONPs}$ injection, and control; (g) the tumor temperature was monitored by the forward-looking infrared (FLIR) thermal camera; (h) Kaplan-Meier curve showing the survival rate of BALB/c mice over time (8 weeks). 


\section{Discussion}

Dendrimers are developing polymeric multivalent system with multiple surface functional groups that have been used in many studies for drug delivery and imaging applications [16,47]. Regarding the potentials of dendrimers for theranostic applications, we functionalized IONPs (size of $10 \pm 4 \mathrm{~nm}$ ) with G4 PAMAM dendrimers and MPEG molecules for magnetic hyperthermia treatment of breast cancer. The amine-terminated PAMAM dendrimers attach to the negatively charged membrane of the cells via electrostatic interactions causing cytotoxicity. The results of this study showed that $\mathrm{G}_{4} @ \mathrm{IONPs}$ cytotoxicity was negligible even at high concentrations, e.g., $500 \mu \mathrm{g} / \mathrm{mL}$, that could be due to PEGylation of $\mathrm{G}_{4} @ I O N P s$ [48]. PEGylation of MNPs has several advantages, such as additional stability, favorable pharmacokinetics, and enhanced therapeutic activity. Moreover, PEGylation can increase the retention time of nanoparticles $[49,50]$. The pharmacokinetics, stability, and retention time of $\mathrm{G}_{4} @ \mathrm{IONPs}$ were assessed in our previous study [36].

The results of Prussian blue staining and ICP-MS showed that $\mathrm{G}_{4} @ I O N P s$ entered into the cytoplasm of the $\mathrm{MC}_{4} \mathrm{~L}_{2}$ cells in a concentration-dependent manner. The surface charge of $\mathrm{G}_{4} @ \mathrm{IONPs}$ was $+35 \mathrm{mV}$; cationic dendrimers possess a high tendency to interact with the bilayer lipid membrane of cells to consequently increase the cellular uptake [51]. PEGylation of $\mathrm{G}_{4} @ \mathrm{IONPs}$ can also alter their cellular uptake via decreasing or preventing the protein adsorption (opsonization) on the $\mathrm{G}_{4} @ \mathrm{IONPs}$ surface [52]. Indeed, higher cellular uptake of MNPs can increase the therapeutic effects of magnetic hyperthermia because more MNPs (heat sources) will be close to cell cytoplasmic proteins and nucleus [53]. Magnetic hyperthermia treatment enhanced the cytotoxic effect of $\mathrm{G}_{4} @ \mathrm{IONPs}$ and decreased the $\mathrm{MC}_{4} \mathrm{~L}_{2}$ cell proliferation; a slight decrease in cell viability in other experimental groups (MNPs and AMF) could be due to $\mathrm{G}_{4} @ \mathrm{OIONPs}$ incubation and AMF exposure, respectively.

Apoptosis is a genetically structured cellular death process activated by several internal and external signals. The intrinsic mitochondrial apoptosis pathway is triggered by intracellular stimuli that upregulate the pro-apoptotic Bcl-2 family of proteins, such as Bax, Bad (Bcl-2 associated agonist of cell death), and Bak (Bcl-2 homologous antagonist/killer), leading to the mitochondrial release of cytochrome C $[54,55]$. This intracellular stress (stimuli) should be strong enough to be able to trigger the apoptosis pathway in the cells; otherwise, some anti-apoptosis molecules would be activated and inhibit the cellular apoptosis procedure. In our study, the magnetic hyperthermia treatment was able to trigger the intrinsic apoptosis pathway and overcome the heat shock proteins (HSP) that cause thermal resistance in cancer cells [56]. TUNEL data approved the MTT viability results; the $\mathrm{G}_{4} @ I O N P s$ entered the cancer cells by endocytosis and produced heat after AMF exposure in the group of MNPs + AMF. These small heat sources could then be the powerful intracellular stimuli to trigger the intrinsic apoptosis pathway in the cancer cell (Figure $3 \mathrm{~h}$ ). The results also showed some apoptosis increase $(P>0.05)$ in the group of AMF, which could be due to eddy current induced in the cell dish during the AMF exposure.

The survivability of treated cancer-bearing BALB/c mice was significantly higher than the untreated ones. This could be because of smaller tumor size in these mice, and, as a result, they could move better in the cage and access to more food and water. Besides that, general health was better in treated mice that helped them to survive longer. The body weight did not show any significant variation during the experimental period that showed our MNPs did not alter the body metabolism in mice. In a similar study, Malik et al. also reported that injecting PAMAM dendrimer $(95 \mathrm{mg} / \mathrm{kg})$ into B16F10 tumor-bearing mice (three times per day) did not alter their weight [57].

Our results showed that the tumor volume in treated mice decreased significantly to $23.7 \%$ of the initial volume $\left(V_{t 0}\right)$ over 27 days. This ratio $\left(V / V_{t 0}\right)$ was $448 \%$ in control animals. Furthermore, tumor volume reduction in other mice (groups of MNPs and AMF) compared to control could be due to intratumoral $\mathrm{G}_{4} @ \mathrm{IONPs}$ injection or AMF exposure. Tumor volume is one of the most important parameters to demonstrate the efficacy of magnetic hyperthermia treatment; therefore, many studies reported the final tumor volume, as well as histopathological outcomes. For instance, Alexanian et al. injected superparamagnetic IONP (SPION) linked to PEG and folic acid (FA-PEG-SPION) into mice 
intravenously and placed them in an alternating current (AC) magnetic field ( $8 \mathrm{kA} / \mathrm{m}$ and $230 \mathrm{kHz})$ for $20 \mathrm{~min}$. They reported that tumor volume in treated mice was one-tenth of control ones 35 days after the last treatment [52].

Tumor regression after magnetic hyperthermia treatment could be due to increasing the cancer cell apoptosis as both in vitro and H\&E results showed that the number of apoptotic cells in the group of MNPs + AMF was significantly more than that in the control group. Furthermore, magnetic hyperthermia treatment decreased the intratumoral microvessel density, which could be another reason for tumor shrinkage in treated mice.

Regarding the effect of magnetic hyperthermia treatment on tumor vascularization, Kossatz et al. investigated the degree of angiogenesis in tumor tissues using the $\mathrm{CD}_{31}$ indicator [23]. To this end, IONPs (25 mg Fe/100 $\mathrm{mm}^{3}$ ) were injected intratumorally, and, after $24 \mathrm{~h}$, nude mice were exposed to an AMF $(15.4 \mathrm{kA} / \mathrm{m}$ and $435 \mathrm{kHz})$. Their results showed that the rate of angiogenesis in treated tumors decreased 28 days after the first treatment. We also obtained similar results regarding tumor angiogenesis suppression with a lower amount of iron injected into the tumor $(5 \mathrm{mg} / \mathrm{mL})$. In our previous study, we showed that $\mathrm{G}_{4} @ \mathrm{IONPs}$ were highly capable of converting AMF energy to heat [21]. Therefore, to generate a sufficient amount of heat inside the tumor, a lesser amount of MNPs was used in our study.

The highest temperature $\left(\max 45^{\circ} \mathrm{C}\right)$, and also temperature uniformity, in the tumor were monitored by a FLIR thermal camera system (Figure $6 \mathrm{~g}$ ) and based on this data, the location and number of MNPs injection sites were determined. The uniformity of heat distribution in the tumor is a determining factor in magnetic hyperthermia treatment [58]. Hence, multiple injection sites (four sites) were applied to obtain a more homogenous MNPs distribution in the tumor. $\mathrm{G}_{4} @ \mathrm{IONPs}(0.1 \mathrm{~mL})$ were gently injected intratumoral using an insulin syringe (Ultra-Fine needle) and after 15 min, the animal was transferred to the AMF coil. No leakage of the MNPs solutions back out was seen after the syringe needle was removed from the tumor.

Our results revealed that treated breast cancer cells (MNPs + AMF) could not progress to invasive ones over time, which could be due to higher apoptosis and necrosis in these cells. Histopathological evaluations were performed by a single-blinded pathologist and Nottingham Histologic Scoring System was used to assess the breast tumor grade. The tumors in treated and control mice were in grades 1 and 3, respectively. In grade 1, the cancer cells look similar to normal cells and usually are well differentiated. Grade 3 breast cancer is invasive, tumors may be larger, and cancer has spread to the lymph nodes $[59,60]$. The treatment could induce differentiation in breast cancer cells, in addition to inhibiting tumor growth. Histopathological studies (H\&E staining) also revealed a higher amount of necrotic cells at the center of treated tumors. Consequently, stem cells at the center of the tumor that are mainly responsible for metastasis and tumor progression would be necrotic after magnetic hyperthermia treatment. This can explain the lack of metastasis and invasive cancer cells in lung and liver tissues in treated animals. On the other hand, it has been indicated that extracellular HSPs trigger antitumor immunity during tumor cell necrosis. Such induced immunity also promotes tumor regression [61].

Overall, magnetic hyperthermia treatment using $\mathrm{G}_{4} @ \mathrm{IONPs}$ increased the cellular apoptosis via the intrinsic apoptosis pathway and at the same time cut the tumor blood supply by decreasing the tumor angiogenesis. These factors inhibited the tumor growth and progression; consequently, cancer cells did not spread and develop metastasis in healthy tissues. The present study has some limitations regarding the MNPs distribution and quantity in the tumor after injection; first, the precise distribution of $\mathrm{G}_{4} @ \mathrm{IONPs}$ could have investigated by magnetic resonance imaging (MRI), confocal microscopy, and Prussian blue staining; second, the iron content in the tumor was not measured after intratumoral $\mathrm{G}_{4} @ \mathrm{IONPs}$ injection. 


\section{Conclusions}

The nanocomposites presented in this study were well-suited for magnetic hyperthermia treatment of breast cancer. The toxicity assay revealed the biocompatibility of $\mathrm{G}_{4} @ I O N P$ s even at high concentrations up to $500 \mu \mathrm{g} / \mathrm{mL}$. Breast cancer cell viability decreased significantly after magnetic hyperthermia treatment. Furthermore, cellular apoptosis increased in treated cancer cells; real time-PCR results also showed that magnetic hyperthermia treatment was able to regulate the expression of the apoptosis-related genes. The dendrimer functionalized IONPs presented here also showed promising outcomes for breast cancer treatment in BALB/c mice. The magnetic hyperthermia treatment decreased tumor mammary gland growth via suppressing the tumor angiogenesis and increasing the cellular necrosis. All in all, $\mathrm{G}_{4} @ \mathrm{IONPs}$ seem to be suitable nanostructures for use in magnetic hyperthermia cancer treatment due to their biocompatibility, stability, and unique structure for the conjugation of biomolecules. For future studies, anti-cancer drugs and imaging contrast agents can be conjugated to the dendrimer coating for cancer theranostics applications.

Author Contributions: Conceptualization, M.S. and R.S.; methodology, M.S.; validation, S.S. and R.S.; formal analysis, M.S.; investigation, M.S. and M.H.; resources, S.S.; data curation, S.S. and R.S.; writing-Original draft preparation, M.S.; writing-Review and editing, all authors; visualization, M.S.; supervision, S.S. and R.S.; project administration, S.S.; funding acquisition, M.S. All authors have read and agreed to the published version of the manuscript.

Funding: This research was funded by Tehran University of Medical Sciences, grant number 28169

Acknowledgments: The authors would like to acknowledge the help with histopathological experiments from Department of Pharmaceutics, Tehran University of Medical Sciences.

Conflicts of Interest: The authors declare no conflict of interest. The funders had no role in the design of the study; in the collection, analyses, or interpretation of data; in the writing of the manuscript, or in the decision to publish the results.

\section{References}

1. Carioli, G.; Malvezzi, M.; Rodríguez, T.; Bertuccio, P.; Negri, E.; La Vecchia, C. Trends and predictions to 2020 in breast cancer mortality: Americas and Australasia. Breast 2018, 37, 163-169. [CrossRef] [PubMed]

2. Bray, F.; Ferlay, J.; Soerjomataram, I.; Siegel, R.L.; Torre, L.A.; Jemal, A. Global cancer statistics 2018: GLOBOCAN estimates of incidence and mortality worldwide for 36 cancers in 185 countries. CA Cancer J. Clin. 2018, 68, 394-424. [CrossRef] [PubMed]

3. Pan, J.; Hu, P.; Guo, Y.; Hao, J.; Ni, D.; Xu, Y.; Bao, Q.; Yao, H.; Wei, C.; Wu, Q.; et al. Combined Magnetic Hyperthermia and Immune Therapy for Primary and Metastatic Tumor Treatments. ACS Nano 2020, 14, 1033-1044. [CrossRef] [PubMed]

4. Gawęda, W.; Osial, M.; Żuk, M.; Pękała, M.; Bilewicz, A.; Krysinski, P. Lanthanide-Doped SPIONs Bioconjugation with Trastuzumab for Potential Multimodal Anticancer Activity and Magnetic Hyperthermia. Nanomaterials 2020, 10, 288. [CrossRef] [PubMed]

5. Mondal, S.; Manivasagan, P.; Bharathiraja, S.; Moorthy, M.S.; Nguyen, V.T.; Kim, H.H.; Nam, S.Y.; Lee, K.D.; Oh, J. Hydroxyapatite Coated Iron Oxide Nanoparticles: A Promising Nanomaterial for Magnetic Hyperthermia Cancer Treatment. Nanomaterials 2017, 7, 426. [CrossRef]

6. Spirou, S.V.; Basini, M.; Lascialfari, A.; Sangregorio, C.; Innocenti, C. Magnetic Hyperthermia and Radiation Therapy: Radiobiological Principles and Current Practice. Nanomaterials 2018, 8, 401. [CrossRef]

7. Brero, F.; Albino, M.; Antoccia, A.; Arosio, P.; Avolio, M.; Berardinelli, F.; Bettega, D.; Calzolari, P.; Ciocca, M.; Corti, M.; et al. Hadron Therapy, Magnetic Nanoparticles and Hyperthermia: A Promising Combined Tool for Pancreatic Cancer Treatment. Nanomaterials 2020, 10, 1919. [CrossRef]

8. $\quad$ Lin, T.-C.; Lin, F.-H.; Lin, J.-C. In vitro feasibility study of the use of a magnetic electrospun chitosan nanofiber composite for hyperthermia treatment of tumor cells. Acta Biomater. 2012, 8, 2704-2711. [CrossRef]

9. Sugahara, T.; Van Der Zee, J.; Kampinga, H.H.; Vujaskovic, Z.; Kondo, M.; Ohnishi, T.; Li, G.; Park, H.J.; Leeper, D.B.; Ostapenko, V.; et al. Kadota Fund International Forum 2004. Application of thermal stress for the improvement of health, 15-18 June 2004, Awaji Yumebutai International Conference Center, Awaji Island, Hyogo, Japan. Final Report. Int. J. Hyperth. 2008, 24, 123-140. [CrossRef] 
10. Takada, T.; Yamashita, T.; Sato, M.; Sato, A.; Ono, I.; Tamura, Y.; Sato, N.; Miyamoto, A.; Ito, A.; Honda, H.; et al. Growth Inhibition of Re-Challenge B16 Melanoma Transplant by Conjugates of Melanogenesis Substrate and Magnetite Nanoparticles as the Basis for Developing Melanoma-Targeted Chemo-Thermo-Immunotherapy. J. Biomed. Biotechnol. 2009, 2009, 1-13. [CrossRef]

11. Etheridge, M.; Manuchehrabadi, N.; Franklin, R.; Bischof, J.; Minkowycz, W.; Sparrow, E.; Abraham, J. Superparamagnetic Iron Oxide Nanoparticle Heating. Comput. Phys. Process. Mech. Therm. Sci. 2012, 97-122. [CrossRef]

12. Ansari, S.A.M.K.; Ficiarà, E.; Ruffinatti, F.A.; Stura, I.; Argenziano, M.; Abollino, O.; Cavalli, R.; Guiot, C.; D'Agata, F. Magnetic Iron Oxide Nanoparticles: Synthesis, Characterization and Functionalization for Biomedical Applications in the Central Nervous System. Materials 2019, 12, 465. [CrossRef] [PubMed]

13. Demirer, G.S.; Okur, A.C.; Kizilel, S. Synthesis and design of biologically inspired biocompatible iron oxide nanoparticles for biomedical applications. J. Mater. Chem. B 2015, 3, 7831-7849. [CrossRef] [PubMed]

14. Esfand, R.; Tomalia, D.A. Poly(amidoamine) (PAMAM) dendrimers: From biomimicry to drug delivery and biomedical applications. Drug Discov. Today 2001, 6, 427-436. [CrossRef]

15. Dufes, C.; Uchegbu, I.F.; Schätzlein, A.G. Dendrimers in gene delivery. Adv. Drug Deliv. Rev. 2005, 57, 2177-2202. [CrossRef]

16. Gillies, E.R.; Fréchet, J.M.J. Dendrimers and dendritic polymers in drug delivery. Drug Discov. Today 2005, 10, 35-43. [CrossRef]

17. Luong, D.; Sau, S.; Kesharwani, P.; Iyer, A.K. Polyvalent Folate-Dendrimer-Coated Iron Oxide Theranostic Nanoparticles for Simultaneous Magnetic Resonance Imaging and Precise Cancer Cell Targeting. Biomacromolecules 2017, 18, 1197-1209. [CrossRef]

18. Alfei, S.; Marengo, B.; Zuccari, G.; Turrini, F.; Domenicotti, C. Dendrimer Nanodevices and Gallic Acid as Novel Strategies to Fight Chemoresistance in Neuroblastoma Cells. Nanomaterials 2020, 10, 1243. [CrossRef]

19. Abbasi, E.; Aval, S.F.; Akbarzadeh, A.; Milani, M.; Nasrabadi, H.T.; Joo, S.W.; Hanifehpour, Y.; Nejati-Koshki, K.; Pashaei-Asl, R. Dendrimers: Synthesis, applications, and properties. Nanoscale Res. Lett. 2014, 9, 247. [CrossRef]

20. Uzun, K.; Çevik, E.; Şenel, M.; Sözeri, H.; Baykal, A.; Abasıyanık, M.F.; Toprak, M.S. Covalent immobilization of invertase on PAMAM-dendrimer modified superparamagnetic iron oxide nanoparticles. J. Nanoparticle Res. 2010, 12, 3057-3067. [CrossRef]

21. Salimi, M.; Sarkar, S.; Saber, R.; Delavari, H.; Alizadeh, A.M.; Mulder, H.T. Magnetic hyperthermia of breast cancer cells and MRI relaxometry with dendrimer-coated iron-oxide nanoparticles. Cancer Nanotechnol. 2018, 9,1-19. [CrossRef] [PubMed]

22. Hayashi, K.; Nakamura, M.; Miki, H.; Ozaki, S.; Abe, M.; Matsumoto, T.; Sakamoto, W.; Yogo, T.; Ishimura, K. Magnetically Responsive Smart Nanoparticles for Cancer Treatment with a Combination of Magnetic Hyperthermia and Remote-Control Drug Release. Theranostics 2014, 4, 834-844. [CrossRef] [PubMed]

23. Kossatz, S.; Grandke, J.; Couleaud, P.; Latorre, A.; Aires, A.; Crosbie-Staunton, K.; Ludwig, R.; Dähring, H.; Ettelt, V.; Lazaro-Carrillo, A.; et al. Efficient treatment of breast cancer xenografts with multifunctionalized iron oxide nanoparticles combining magnetic hyperthermia and anti-cancer drug delivery. Breast Cancer Res. 2015, 17, 1-17. [CrossRef] [PubMed]

24. Paknikar, K.M.; Haghniaz, R.; Umrani, R.D. Hyperthermia mediated by dextran-coated La0.7Sr0.3MnO3 nanoparticles: In vivo studies. Int. J. Nanomed. 2016, 11, 1779-1791. [CrossRef] [PubMed]

25. Lee, J.-H.; Jang, J.-T.; Choi, J.-S.; Moon, S.H.; Noh, S.-H.; Kim, J.-W.; Kim, J.-G.; Kim, I.-S.; Park, K.I.; Cheon, J. Exchange-coupled magnetic nanoparticles for efficient heat induction. Nat. Nanotechnol. 2011, 6, 418-422. [CrossRef] [PubMed]

26. Li, T.-J.; Huang, C.-C.; Ruan, P.-W.; Huang, K.-J.; Shieh, D.-B.; Yeh, C.-S. In vivo anti-cancer efficacy of magnetite nanocrystal-based system using locoregional hyperthermia combined with 5-fluorouracil chemotherapy. Biomaterials 2013, 34, 7873-7883. [CrossRef] [PubMed]

27. Rabias, I.; Tsitrouli, D.; Karakosta, E.; Kehagias, T.; Diamantopoulos, G.; Fardis, M.; Stamopoulos, D.; Maris, T.G.; Falaras, P.; Zouridakis, N.; et al. Rapid magnetic heating treatment by highly charged maghemite nanoparticles on Wistar rats exocranial glioma tumors at microliter volume. Biomicrofluidics 2010, 4, 024111. [CrossRef] 
28. Bae, K.H.; Park, M.; Do, M.J.; Lee, N.; Ryu, J.H.; Kim, G.W.; Kim, C.; Park, T.G.; Hyeon, T. Chitosan Oligosaccharide-Stabilized Ferrimagnetic Iron Oxide Nanocubes for Magnetically Modulated Cancer Hyperthermia. ACS Nano 2012, 6, 5266-5273. [CrossRef]

29. Ling, Y.; Tang, X.; Wang, F.; Zhou, X.; Wang, R.; Deng, L.; Shang, T.; Liang, B.; Li, P.; Ran, H.; et al. Highly efficient magnetic hyperthermia ablation of tumors using injectable polymethylmethacrylate-Fe3O4. RSC Adv. 2017, 7, 2913-2918. [CrossRef]

30. Arriortua, O.K.; Garaio, E.; De La Parte, B.H.; Insausti, M.; Lezama, L.; Plazaola, F.; García, J.A.; Aizpurua, J.M.; Sagartzazu, M.; Irazola, M.; et al. Antitumor magnetic hyperthermia induced by RGD-functionalized Fe3O4 nanoparticles, in an experimental model of colorectal liver metastases. Beilstein J. Nanotechnol. 2016, 7, 1532-1542. [CrossRef]

31. Ohtake, M.; Umemura, M.; Sato, I.; Akimoto, T.; Oda, K.; Nagasako, A.; Kim, J.-H.; Fujita, T.; Yokoyama, U.; Nakayama, T.; et al. Hyperthermia and chemotherapy using Fe(Salen) nanoparticles might impact glioblastoma treatment. Sci. Rep. 2017, 7, 42783. [CrossRef] [PubMed]

32. Sato, I.; Umemura, M.; Mitsudo, K.; Fukumura, H.; Kim, J.-H.; Hoshino, Y.; Nakashima, H.; Kioi, M.; Nakakaji, R.; Sato, M.; et al. Simultaneous hyperthermia-chemotherapy with controlled drug delivery using single-drug nanoparticles. Sci. Rep. 2016, 6, 24629. [CrossRef] [PubMed]

33. Yang, Y.; Wang, F.; Zheng, K.; Deng, L.; Yang, L.; Zhang, N.; Xu, C.; Ran, H.; Wang, Z.; Wang, Z.; et al. Injectable PLGA/Fe3O4 implants carrying cisplatin for synergistic magnetic hyperthermal ablation of rabbit VX2 tumor. PLoS ONE 2017, 12, e0177049. [CrossRef] [PubMed]

34. Zhang, Z.-Q.; Song, S.-C. Multiple hyperthermia-mediated release of TRAIL/SPION nanocomplex from thermosensitive polymeric hydrogels for combination cancer therapy. Biomaterials 2017, 132, 16-27. [CrossRef] [PubMed]

35. Hayashi, K.; Nakamura, M.; Sakamoto, W.; Yogo, T.; Miki, H.; Ozaki, S.; Abe, M.; Matsumoto, T.; Ishimura, K. Superparamagnetic Nanoparticle Clusters for Cancer Theranostics Combining Magnetic Resonance Imaging and Hyperthermia Treatment. Theranostics 2013, 3, 366-376. [CrossRef] [PubMed]

36. Salimi, M.; Sarkar, S.; Fathi, S.; Alizadeh, A.M.; Saber, R.; Moradi, F.; Delavari, H. Biodistribution, pharmacokinetics, and toxicity of dendrimer-coated iron oxide nanoparticles in BALB/c mice. Int. J. Nanomed. 2018, 13, 1483-1493. [CrossRef] [PubMed]

37. Shirshahi, V.; Hatamie, S.; Tabatabaei, S.N.; Salimi, M.; Saber, R. Enhanced Thermal Stability and Biocompatibility of Gold Nanorods by Graphene Oxide. Plasmonics 2017, 13, 1585-1594. [CrossRef]

38. Hsiao, I.-L.; Bierkandt, F.S.; Reichardt, P.; Luch, A.; Huang, Y.-J.; Jakubowski, N.; Tentschert, J.; Haase, A. Quantification and visualization of cellular uptake of $\mathrm{TiO} 2$ and $\mathrm{Ag}$ nanoparticles: Comparison of different ICP-MS techniques. J. Nanobiotechnol. 2016, 14, 1-13. [CrossRef]

39. Wang, Z.; Cuschieri, A. Tumour Cell Labelling by Magnetic Nanoparticles with Determination of Intracellular Iron Content and Spatial Distribution of the Intracellular Iron. Int. J. Mol. Sci. 2013, 14, 9111-9125. [CrossRef]

40. Hashemi, M.; Fallah, A.; Aghayan, H.R.; Arjmand, B.; Yazdani, N.; Verdi, J.; Ghodsi, S.M.; Miri, S.M.; Hadjighassem, M. A New Approach in Gene Therapy of Glioblastoma Multiforme: Human Olfactory Ensheathing Cells as a Novel Carrier for Suicide Gene Delivery. Mol. Neurobiol. 2015, 53, 5118-5128. [CrossRef]

41. Livak, K.J.; Schmittgen, T.D. Analysis of relative gene expression data using real-time quantitative PCR and the $2^{-\Delta \Delta C t}$ method. Methods 2001, 25, 402-408. [CrossRef] [PubMed]

42. Elston, C.; Ellis, I. pathological prognostic factors in breast cancer. I. The value of histological grade in breast cancer: Experience from a large study with long-term follow-up. Histopathology 1991, 19, 403-410. [CrossRef] [PubMed]

43. Ufuk, G.; Unsoy, G.; Yalcın, S.; Gunduz, G.; Gunduz, U. PAMAM dendrimer-coated iron oxide nanoparticles: Synthesis and characterization of different generations. J. Nanoparticle Res. 2013, 15, 1-13. [CrossRef]

44. Yamaura, M.; Camilo, R.; Sampaio, L.; Macêdo, M.; Nakamura, M.; Toma, H. Preparation and characterization of (3-aminopropyl)triethoxysilane-coated magnetite nanoparticles. J. Magn. Magn. Mater. 2004, 279, $210-217$. [CrossRef]

45. Tsubokawa, N.; Takayama, T. Surface modification of chitosan powder by grafting of 'dendrimer-like' hyperbranched polymer onto the surface. React. Funct. Polym. 2000, 43, 341-350. [CrossRef]

46. Julian, J.M.; Brezinski, D.R. An Infrared Spectroscopy Atlas for the Coatings Industry; Federation of Societies for Paint Technology: Plymouth, PA, USA, 1991. 
47. Nanjwade, B.K.; Bechra, H.M.; Derkar, G.K.; Manvi, F.; Nanjwade, V.K. Dendrimers: Emerging polymers for drug-delivery systems. Eur. J. Pharm. Sci. 2009, 38, 185-196. [CrossRef]

48. Kojima, C.; Turkbey, B.; Ogawa, M.; Bernardo, M.; Regino, C.A.S.; Bryant, L.H.; Choyke, P.L.; Kono, K.; Kobayashi, H. Dendrimer-based MRI contrast agents: The effects of PEGylation on relaxivity and pharmacokinetics. Nanomed. Nanotechnol. Biol. Med. 2011, 7, 1001-1008. [CrossRef]

49. Mishra, P.; Nayak, B.; Dey, R.K. PEGylation in anti-cancer therapy: An overview. Asian J. Pharm. Sci. 2016, 11, 337-348. [CrossRef]

50. Harris, J.M.; Chess, R.B. Effect of pegylation on pharmaceuticals. Nat. Rev. Drug Discov. 2003, 2, $214-221$. [CrossRef]

51. Mecke, A.; Majoros, I.J.; Patri, A.K.; Baker, J.J.R.; Holl, M.M.B.; Orr, B.G. Lipid Bilayer Disruption by Polycationic Polymers: The Roles of Size and Chemical Functional Group. Langmuir 2005, 21, 10348-10354. [CrossRef]

52. Wood, A.J.; Alexanian, R.; Dimopoulos, M. The Treatment of Multiple Myeloma. N. Engl. J. Med. 1994, 330, 484-489. [CrossRef] [PubMed]

53. Laurent, S.; Dutz, S.; Häfeli, U.O.; Mahmoudi, M. Magnetic fluid hyperthermia: Focus on superparamagnetic iron oxide nanoparticles. Adv. Colloid Interface Sci. 2011, 166, 8-23. [CrossRef] [PubMed]

54. Linehan, W.M.; Walther, M.M.; Zbar, B. The Genetic Basis of Cancer of the Kidney. J. Urol. 2003, 170, 2163-2172. [CrossRef] [PubMed]

55. You, Y.; Cheng, A.; Wang, M.-S.; Jia, R.-Y.; Sun, K.-F.; Yang, Q.; Wu, Y.; Zhu, D.; Chen, S.; Liu, M.-F.; et al. The suppression of apoptosis by $\alpha$-herpesvirus. Cell Death Dis. 2017, 8, e2749. [CrossRef] [PubMed]

56. Ikwegbue, P.C.; Masamba, P.; Oyinloye, B.E.; Kappo, A.P. Roles of Heat Shock Proteins in Apoptosis, Oxidative Stress, Human Inflammatory Diseases, and Cancer. Pharmaceuticals 2017, 11, 2. [CrossRef] [PubMed]

57. Malik, N.; Evagorou, E.G.; Duncan, R. Dendrimer-platinate: A novel approach to cancer chemotherapy. Anti-Cancer Drugs 1999, 10, 767-776. [CrossRef]

58. Du, Y.; Liu, X.; Liang, Q.; Liang, X.-J.; Tian, J. Optimization and Design of Magnetic Ferrite Nanoparticles with Uniform Tumor Distribution for Highly Sensitive MRI/MPI Performance and Improved Magnetic Hyperthermia Therapy. Nano Lett. 2019, 19, 3618-3626. [CrossRef]

59. Giuliano, A.E.; Edge, S.B.; Hortobagyi, G.N. Eighth Edition of the AJCC Cancer Staging Manual: Breast Cancer. Ann. Surg. Oncol. 2018, 25, 1783-1785. [CrossRef]

60. Singletary, S.E.; Allred, C.; Ashley, P.; Bassett, L.W.; Berry, D.; Bland, K.I.; Borgen, P.I.; Clark, G.; Edge, S.B.; Hayes, D.F.; et al. Revision of the American Joint Committee on Cancer Staging System for Breast Cancer. J. Clin. Oncol. 2002, 20, 3628-3636. [CrossRef]

61. Zhu, J.; Zhang, Y.; Zhang, A.; He, K.; Liu, P.; Xu, L.X. Cryo-thermal therapy elicits potent anti-tumor immunity by inducing extracellular Hsp70-dependent MDSC differentiation. Sci. Rep. 2016, 6, 27136. [CrossRef]

Publisher's Note: MDPI stays neutral with regard to jurisdictional claims in published maps and institutional affiliations.

(C) 2020 by the authors. Licensee MDPI, Basel, Switzerland. This article is an open access article distributed under the terms and conditions of the Creative Commons Attribution (CC BY) license (http://creativecommons.org/licenses/by/4.0/). 